\title{
MOMENT CONTRIBUTION CAPACITY OF TENDON PRESTRESSED PARTIAL ON CONCRETE BEAM-COLUMN JOINT INTERIOR ACCORDING TO PROVISIONS ACI 318-2008 CHAPTER 21.5.2.5(c) DUE TO CYCLIC LATERAL LOADS
}

\author{
Made Dharma Astawa ${ }^{1}$, IGusti Putu Raka ${ }^{2}$, Tavio $^{3}$ \\ ${ }^{1}$ Civil Engineering Departement, University of Pembangunan Nasional"Veteran", Surabaya-East-Java- Indonesia and Doctoral Student \\ of Civil Engineering (structure), Faculty of Civil Engineering and Planning-ITS Surabaya-Indonesia. \\ ${ }^{2,3}$ Profesor at Department of Civil Engineering, Faculty of Civil Engineering and Planning-ITS, Surabaya. \\ E-mail: mdastawa@upnjatim.ac.id, masdawa@yahoo.com
}

\begin{abstract}
This research designed a partial prestressed concrete beam-column with reinforced concrete interior joint, using square columns of 400/400 mm, reinforcement 6 D16 + 4D13, section beam 250/400 mm, tensile reinforcement 5 D13, compression reinforcement $3 \mathrm{D} 13+2$ strand tendon D12,7 mm, and joint without plastic hinge, then tested in laboratory with lateral cyclic loads on peak column, static axial load $1120 \mathrm{kN}$ on the centre column, to get the tendon capacity to assume positive and negative bending moments due to lateral load, according to provisions of ACI 318-2008 part 21.5.2.5 (c). Test results showed that the moment tendon contribution on beam section, in the tensile area, the positive and negative moment both on the left side or the right side column are all qualified $(<25 \%)$. In compression area, the positive moments on left and right columns are not qualified at all $(>25 \%)$. As for the negative moment, either left or right side column are all qualified $(<25 \%$ ). Ductility, compression, and tensile ductility on drift ratio $3.50 \%$ are all qualified (>4.0). Although the contribution of positive moment capacity tendon in compression areas does not qualify, in overall, the reliability and ductility of the structure qualify.
\end{abstract}

Keywords: Interior beam-column joint, partial prestressed, tendon moment contribution, ductility.

\section{INTRODUCTION}

In Storey Frame Building Structure design, especially in areas of Strong Earthquake Region, shall be designed with earthquake resistance (SNI 03-1726-2012). This research aimed to design a model element beamcolumn joint structure capable of ductile behavior during the earthquake lateral work on the building frame structure (Purwono R et al., 2005). The Beam-column joint is composed of the elements of column reinforced concrete partially prestressed concrete beams, that monolithicly connects without special plastic hinge design (Blakeley \& Park., 1971). In another reference, a comparative study on exterior RCC beam-column joint is subjected to monotonic loading (S.V. Chaudhari et al., 2014).

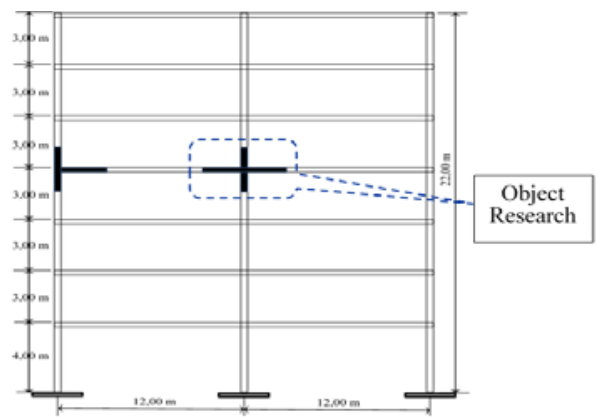

Figure-1. Focus object of research

The selection of the model 's structure, especially on long-span beam structure would be more economical than full Prestressed Concrete structures in Building Structures. Due to the structure analysis of prestressed full strength, the tendon is considered to work with full withstand bending loads, regardless of the share of the burden of reinforcing steel bending. The steel is considered as installed practical reinforcement so that the design would have less economical structure (Lin., 2002). An illustration of Beam-Column Joint allocation to be studied is shown in the picture of building's Framework above.

\section{Significance of Research \\ Referring to the design of Beam - Column Joint} models with elements of Partial Prestressed Concrete Beam-Reinforced Concrete Column Interior, forming a partnership between the strand tendon and rebars in bearing of bending load and lateral load is based on references as follows: acceptance criteria of the moment frames based on structural testing and commentary (Ronald Klemencic et al., 2005), guide for testing reinforced concrete structural elements under slowly applied simulated seismic loads (Sergio M Alcocer et al., 2013), proposed revisions to 1997 NEHRP recommended provisions for seismic regulations for precast concrete structures Part-2, and seismic force resisting system (Hawkins \& Gosh., 2000). The prestressing steel shall not contribute to more than one-quarter of the positive or negative flexural strength at the critical section in a plastic hinge region and shall be anchored at or beyond the exterior face of the joint. (ACI 318, 2008).

This research aimed to calculate the contribution of tendon moment capacity in total moment beams capacity at the Joint Bearing and the level of ductility Joint Structure Interior. From this study, it was expected to give a result in a more economical of design structure than the full Prestressed Concrete Beams structure, especially for buildings that need to widen the span of the rooms (in concept) (Made D Astawa et al., 2013).

\section{Specimen Beam-Column Joint Interior}

There is one piece of Model Structure BeamColumn Joint Interior, with full-scale design, which is using Partial Prestressed Concrete Beams elementsReinforced Concrete Columns, by referring to the 
procedure for calculation of concrete structures for building construction (SNI 03, 2013).

\section{METHODOLOGY}

First, we made the one piece specimen of BeamColumn Joint with Partial Prestressed Concrete Beams element-Column Reinforced Concrete, specimen forming of mold, and then the concrete was cast. After 28 days, the initial force prestressed of beams (stressing) was given. Within an interval of 24 hours, the specimens were tested with static axial loads and lateral cyclic loads on the peak of the column.

\section{Design of Load}

Lateral load plan is cyclic load, the magnitude of the lateral cyclic loading work is controlled by the Drift ratio ranging from $0.00 \%$ to $3.50 \%$, according to NEHRP 1997 or ACI 318-2008, ACI 374.1-05 and 374.2R-13, that is categorized as Cyclic load (pseudo-dynamic). Determining Drift achievement ratio of $3.50 \%$ is enough to evaluate the qualified ductile structure. Axial load static vertical column has a stability of the structure by $1120 \mathrm{kN}$.

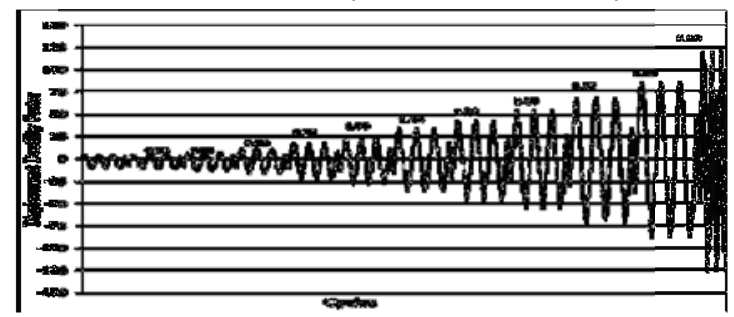

Figure-2. Cyclic Load Diagram(Hawkins \& Gosh, 2000) Test Set-up Spesimen

The test specimens were conducted using the actuator with a loading capacity of $1000 \mathrm{kN}$ for lateral load and $2000 \mathrm{kN}$ for vertical loading.

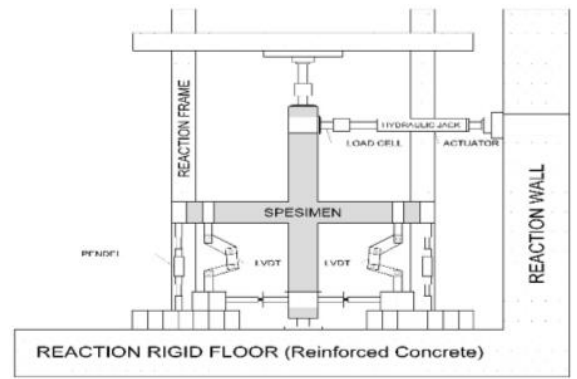

Figure-3. Models test set-up Specimens

\section{Design of Partial Prestressed Beams elements}

The dimension of the beam section was made to $250 / 400 \mathrm{~mm}$, concrete cover is made of $35 \mathrm{~mm}$ thick with the following Materials Properties:

Top Reinforced 5D13 with As $=663.7 \mathrm{~mm}^{2}$ Bottom Reinforced 3D13 with As=398.2 $\mathrm{mm}^{2}$ Using 1 tendons and 2 strands, with diameter $(\mathrm{D})=12.7$ $\mathrm{mm}$, sectional area Aps $=2(98.71)=197.42 \mathrm{~mm}^{2}$, and fps $=1030 \mathrm{Mpa}$. In order to meet the requirements of under-reinforced, then:

$$
\omega_{\mathrm{p}}=\frac{\text { A ps }_{\mathrm{pss}}}{\text { b.d. } \mathrm{f}_{\mathrm{c}}^{\prime}} \leq 0,3
$$

Effective high $\mathrm{d}=400-35-\varnothing 8-1 / 2 \mathrm{D}_{13}=350,5 \mathrm{~mm}$

$\omega_{\mathrm{p}}=\frac{197,42(1030)}{250(350,5) 40}=0,06<0,3 \ldots(\mathrm{OK})$

Comparing the tendon section area and concrete section area according to ACI and UBC, then:

$\frac{197,42}{250.400}=0,002<0,007 \ldots(\mathrm{OK})$
The effective high requirements of concrete compressive stress block are taken: $\mathrm{a}=0,235 \mathrm{~d} \leq 0,2 \mathrm{~h} \mathrm{~s} / \mathrm{d} 0,25 \mathrm{~h}$ $\mathrm{a}=0.235(350.5)=82.4 \mathrm{~mm} \leq 0.25(400) ; 82.4<100 \ldots(\mathrm{OK})$. Spacing stirrup partially prestressed beams (ParkThompson, 1980) is between 1" to 7" (25.4 mm-78 $\mathrm{mm}$ ), and chosen $\varnothing 8-75 \mathrm{~mm}$, so it is in accordance to the provisions.

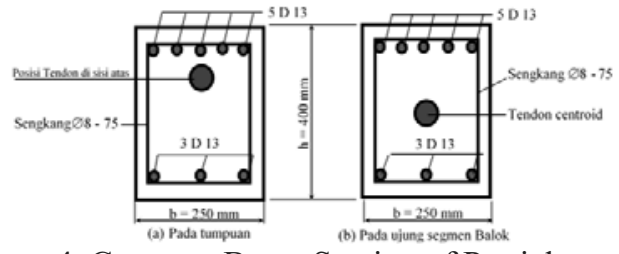

Figure-4. Concrete Beam Section of Partial prestressed Flexural beam load capacity

Nominal Momen $\mathrm{Mn}=\mathrm{T}(\mathrm{d}-\mathrm{a} / 2)=(663,7.400)$

$(350,5-1 / 2.82,4) 10^{-6}=82,12 \mathrm{kNm}$

Tensile capacity of prestressed tendons is:

$\mathrm{f}_{\mathrm{n}}=\mathrm{f}_{\mathrm{ps}} \cdot A_{\mathrm{ps}}=1030$ (197.42). $10^{-3}=203.34 \mathrm{kN}$

With Partial Prestressing Ratio (PPR):

PPR $=\frac{A_{p s} \cdot f_{p s}\left(d_{p}-\frac{a}{2}\right)}{A_{p s} \cdot f_{p s}\left(d_{p}-\frac{a}{2}\right)+A_{s} \cdot f_{y}\left(d_{s}-\frac{a}{2}\right)}$

Should meet: $0<P P R<1$

$\mathrm{PPR}=0.56$, then $0<0.56<1 \ldots(\mathrm{OK})$

Effective high beam is computed from Tendons:

$\mathrm{d}_{\mathrm{p}}=400-35-8-25-25-50 / 2=282 \mathrm{~mm}$

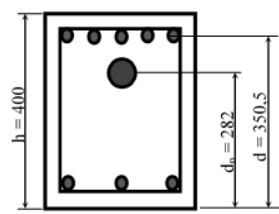

Figure-5. The effective high beam

Controls global reinforcing index, $(\omega)$, is the ratio of strand tendons and reinforcement used for calculation of moments of a strong structural component:

$\omega=\omega_{\mathrm{p}}+\omega_{\mathrm{s}}-\omega_{\mathrm{s}}^{\prime} \leq 0,36 \beta_{1}$,

After the calculated: $\beta_{1}=0.77 ; \omega_{\mathrm{p}}=0.06 ; \omega_{\mathrm{s}}=0.076$; $\omega_{\mathrm{s}}$ ' $=0.045$, making: $\omega=0,06+0,076-0,045=0,091$ $\omega<0,36 \beta_{1} \rightarrow 0,091<0,36.0,77 \rightarrow 0,091<0,277 \ldots(\mathrm{OK})$ Horizontal Actuator capacity $=1000 \mathrm{kN}$, effective $80 \%=$ $0.8(1000)=800 \mathrm{kN}$. In the design of load capacity of the structure, all of the conditions of the structure specimens were taken into account in the elastic state, so the structure has not cracked.

Actuator moment due to lateral forces $\mathrm{P}$ :

$800 \mathrm{kN}(1.00) . \mathrm{m}=800 \mathrm{kNm}$, this became the primary moments. The members' stiffness:

After the calculation: $k_{1,3}=\frac{3 E I_{1}}{L_{1}}=4,0 ; \mathrm{k}_{2,4}=\frac{3 \cdot \mathrm{EI}_{2}}{\mathrm{~L}_{2}}=6,4$

With moment distribution factors:

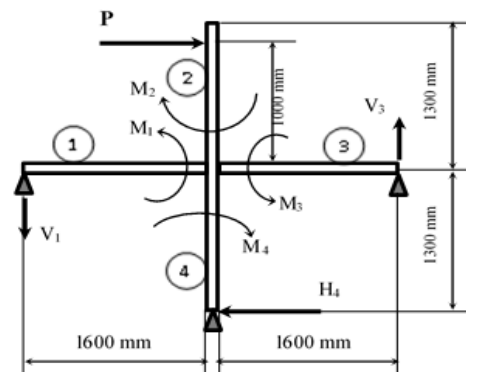

Figure-6. Distribution Moment on specimens $\mathrm{fd}_{1}=\mathrm{fd}_{3}=\frac{\mathrm{k}_{1}}{\mathrm{k}_{1}+\mathrm{k}_{2}+\mathrm{k}_{3}+\mathrm{k}_{4}}=0,19 ; \mathrm{fd}_{2}=\mathrm{fd}_{4}=\frac{\mathrm{k}_{2}}{\sum \mathrm{k}}=0,31$ 
$\mathrm{M}_{1}=\mathrm{M}_{3}=0.19(800)=152 \mathrm{kNm} ; \mathrm{M}_{2}=\mathrm{M}_{4}=0.31(800)$

$=248 \mathrm{kNm}$, Momen of Reinforcement:

$\mathrm{M}_{\mathrm{n} 1}=$ As. $\mathrm{fy}(\mathrm{d}-\mathrm{a} / 2)=663,7.400(365-82,4 / 2) 10^{-6}=85,96 \mathrm{kNm}$

Mn of Tendon Prestressed:

$\mathrm{X}=\mathrm{a} / \beta_{1}=82.4 / 0.77=107 \mathrm{~mm} ; \mathrm{e}=282-107=175 \mathrm{~mm}$

$\mathrm{M}_{\mathrm{n} 2}=\mathrm{F}(\mathrm{e})=203.34(175) \cdot 10^{-3}=35.58 \mathrm{kNm}$

Design of elements Reinforced Concrete Columns

The dimension of column sectional is $400 / 400 \mathrm{~mm}$.

a. Column reinforcing and stirrup design

According to SNI 03-2847-2002 (part 23.4.3), column longitudinal reinforcing ratio is taken between $0.01 \leq \rho_{\mathrm{g}} \leq$ 0.06. In this design, it was taken as $\rho_{\mathrm{g}(\min )}=0,01$, so it still qualifies.

Reinforcing section area $\mathrm{As}=\rho_{\mathrm{g}} . \mathrm{Ag}=0.01(400.400)=$ $1600 \mathrm{~mm}^{2}$, used $6 \mathrm{D}_{16}+4 \mathrm{D}_{13}=1837.3 \mathrm{~mm}^{2}$.

The sectional area of stirrups was taken from value equation according to the capture SNI 03-2847-2002 (section 23.4.4) for a square-shaped stirrup as follows:

$A_{\text {sh }}=0,09\left(\frac{s \cdot h_{c} \cdot f_{c}^{\prime}}{f_{y h}}\right)$

The outer clearance between stirrups is 400 $2(40)=320 \mathrm{~mm}$, while stirrups range from center to center towards high column $=320-10=310 \mathrm{~mm}$, so that: $h_{c}$ $=310 \mathrm{~mm}$, and stirrups range is determined as $50 \mathrm{~mm}$ (for single stirrups). The sectional area of horizontal stirrups, after the calculation, was: $A_{s h}=139.50 \mathrm{~mm}^{2}$; while sectional area one foot:

$\mathrm{A}_{\mathrm{sh}} 1=139.5 / 2=69.75<$ area $1 \varnothing 10=78.50 \mathrm{~mm}^{2} \ldots(\mathrm{OK})$

Planning of shear stirrups in the joint

According to the provisions of SNI 03-28472002 part 23.4.4):

$A_{s h}=0,3\left(\frac{s \cdot h_{c} \cdot f_{c}^{\prime}}{f_{y h}}\right)\left[\left(\frac{A_{g}}{A_{c h}}\right)-1\right]$

Or $A_{s h}=0,09\left(\frac{s \cdot h_{c} \cdot f_{c}^{\prime}}{f_{y h}}\right)$ Stirrups of $\varnothing 10$, cover of concrete

$=40 \mathrm{~mm}$

$\mathrm{A}_{\mathrm{ch}}=(320)(320)=102400 \mathrm{~mm}^{2} ; \mathrm{h}_{\mathrm{c}}=20-2(0.5 .10)=310 \mathrm{~mm}$.
Stirrups space S, was taken as $50 \mathrm{~mm}$

After the calculation:

$\mathrm{M}_{\mathrm{n}}=\mathrm{M}_{\mathrm{n} 1}+25 \%\left(\mathrm{M}_{\mathrm{n} 2}\right)=85.96+0.25(35.58)=94.86 \mathrm{kNm}$ $<152 \mathrm{kNm}(\mathrm{OK}) \mathrm{A}_{\mathrm{sh}}=261.56 \mathrm{~mm}^{2}$; or $\mathrm{A}_{\mathrm{sh}}=139 \mathrm{~mm}^{2}$, used a great value; $1 \emptyset 10 \rightarrow \mathrm{As}=78,5 \mathrm{~mm}^{2}$. With the amount of stirrups: $261.56 / 78.5=3.33$, it takes 4 stirrups, but since $\mathrm{S}=50 \mathrm{~mm}$ and an empty of high space beam $=400-2(35)-2(8)-2(13)=288 \mathrm{~mm}$, we used the amount of stirrups $=288 / 50=5.76$ rounded as 6 pieces with $A_{\text {sh }}=$ $471 \mathrm{~mm}^{2}$.

The calculation of shear strength of joint is:

$\mathrm{V}_{\text {col }}=\frac{2 \mathrm{~T}_{\mathrm{b}} \cdot \mathrm{Z}_{\mathrm{b}}+\mathrm{V}_{\mathrm{b}} \cdot \mathrm{h}_{\mathrm{c}}}{\mathrm{l}_{\mathrm{c}}}$

$\mathrm{V}_{\text {jh }}=\mathrm{V}_{\mathrm{col}}\left(\frac{\mathrm{l}_{\mathrm{c}}}{\mathrm{Z}_{\mathrm{b}}}-1\right)-\mathrm{V}_{\mathrm{b}}\left(\frac{\mathrm{h}_{\mathrm{c}}}{\mathrm{Z}_{\mathrm{b}}}\right)$

$\mathrm{V}_{\mathrm{b}}=0.4$. 0.25. 24(1.6) $+192 / 1.6=123.84 \mathrm{kN}$

After the calculation: $\mathrm{V}_{\text {col }}=68 \mathrm{kN} ; \mathrm{V}_{\mathrm{jh}}=274.30 \mathrm{kN}$.

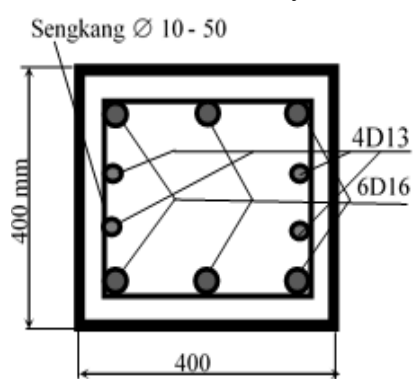

Figure-7. Sectional Reinforced Concrete Columns

\section{Fabrication and assembling specimen}

Cutting and bistaat reinforcement in such a way was adapted to the design of beam-column joint specimens Interior. Furthermore, assembling was done according to the shape of the specimen Interior. The results of the model specimen assemblies are as illustrated in the following figure:

Table-1. Recapitulation specification Beam-Column Joint specimens

\begin{tabular}{|c|c|c|c|c|c|}
\hline $\begin{array}{c}\text { Type of } \\
\text { Structure }\end{array}$ & $\begin{array}{c}\text { Element of Structure } \\
(\mathbf{m m})\end{array}$ & Reinforcement & Stirrups & $\begin{array}{l}\text { Tendon } \\
\text { quantity }\end{array}$ & $\begin{array}{c}\text { Specimen } \\
\text { amount }\end{array}$ \\
\hline \multirow{3}{*}{$\begin{array}{l}\text { Interior Beam- } \\
\text { Column Joint }\end{array}$} & Beam & Pull Reinforced 5D 13 & \multirow{2}{*}{$\varnothing 8-75$} & \multirow{2}{*}{$1(2$ strand $)$} & \multirow{3}{*}{ 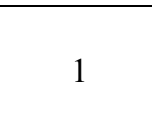 } \\
\hline & $250 / 400$ & Press Reinforced $3 \mathrm{D}_{13}$ & & & \\
\hline & Column 40/40 & $6 \mathrm{D}_{16}+4 \mathrm{D}_{13}$ & $\varnothing 10-50$ & - & \\
\hline
\end{tabular}

\section{LVDT, Wire-gauge, and Starin-gauge}

Linear Variable Displacement Transducer (LVDT), Wire-Gauge (WG) and Strain-Gauge (SG) are used to measure the amount of strain due to deformation (dift) on the specimen when the cyclic lateral load works. LVDT and WG were installed on the outside of the columns and beams while SG was installed on the fiber outer parts.

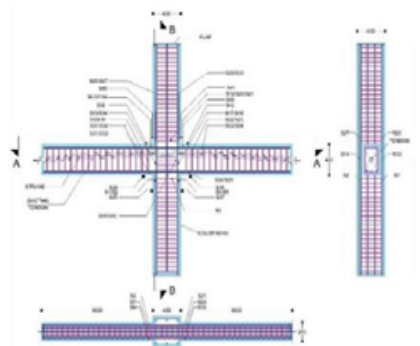

Figure-8. Joint specimen Plan and mounting location Strain Gauge
Concrete beams and columns inside of the Joint were pulled and pressed while SG for reinforcement and Strand was installed in each reinforcement beams and columns and Strand on the side of the joint.

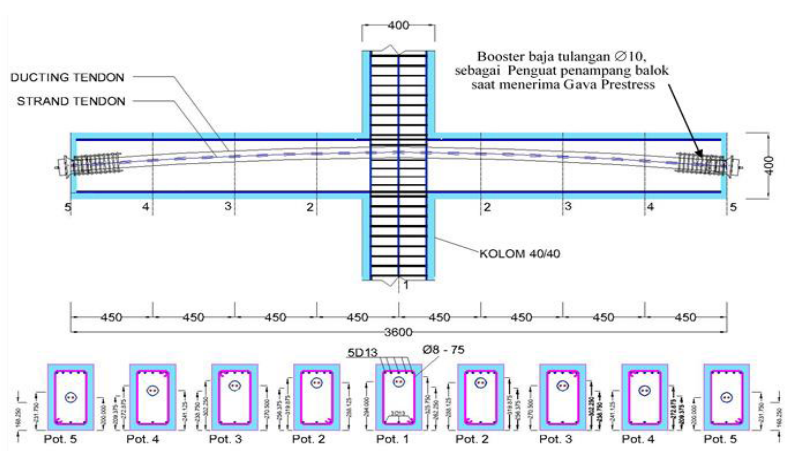

Figure-9. Regions plan Curved Tendons 


\section{Scope of Analysis}

\section{Moment contribution of Tendon Analysis}

Moment tendon contribution at the moment capacity of the beam is according to the provisions ACI 318-2008 part 21.5.2.5(c) which were $\leq 25 \%$ from total capacity, both positive and negative moments.

\section{Structure Ductility}

Ductility analysis of structure was taken from the maximum lateral deformation which is proportional to the initial deformation structure.

\section{RESULTS}

\section{Hysteretic curve test results}

Test results used hysteretic curve data, with several sensors were installed at critical points, among others: Linear Variable Displacement Transducer (LVDT), Wire-gauge (WG) and Starain-gauge (SG). Each outcome data, at any point, will be presented sequentially in the form of graphs.

Hysteretic curve Wire-gauge (WG) was mounted on one point, top of the column, because the maximum lateral deformation will occur at the top of the column at the location of the working force by means of Cyclic Lateral Horizontal Actuator. Results of Wire-gauge recordings are perfect for maximum strain deformation capability of these tools, up to $500 \mathrm{~mm}$, so the deformation of the wire specimen is not high enough to break up. The Curves of Hysteritic LVDT and WG on top of the column as a representative of other points are as follows:
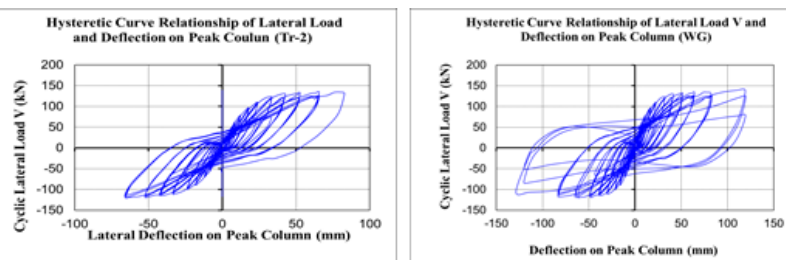

Figure-10. Hysteretic Curve Figure-11. Hysteretic Curve LVDT on Peak Column

WG on Peak Column Hysteretic curves Strain-gauge (SG) beam are represented by the SG-6, SG-7 and SG-8, while for reinforcement Pull the right side of the column were represented by SG-19, SG-20 and SG-21. As for the press and the left side of the column, reinforcement is represented by SG-11 and SG12 , on the right side column is of the SG-24 and SG-25. SG-24 is dead, but that only represented the SG-25. Strain Gauge Strand Tendons is attached to the left column SG31 and SG-32, while right-hand column is of the SG-33 and SG-34, but only SG-31 that lives, so it only represented the SG-31 alone. SG Picture Hysteritic curve will be presented just as the following. Keep in mind that the conditions recorded by the strain-gauge can not be as perfect as that of recorded by the LVDT.

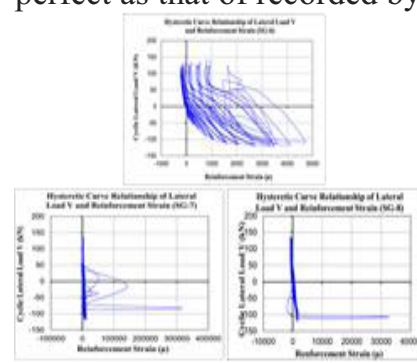

Figure-12. Curve hysteretic

SG on Tensile reinforcement the left side column

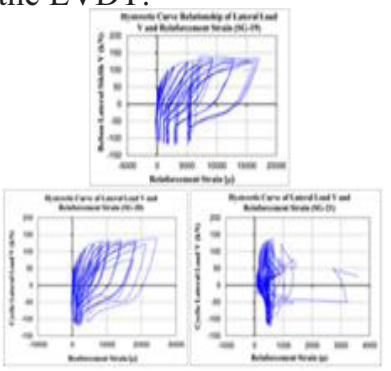

Figure-13. Curve hysteretic

SG on Tensile reinforcement the right side column
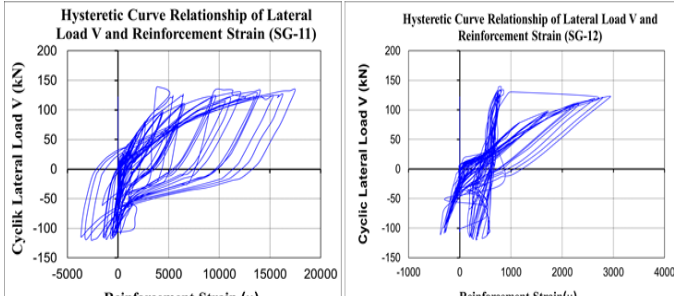

Figure-14. Curve hysteretic SG on Press reinforcement on the left side column
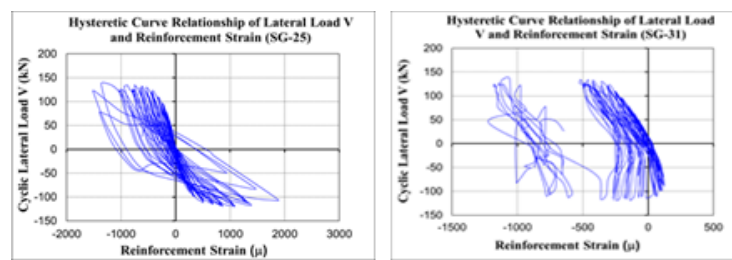

Figure-15. Curve hysteretic SG Figure-16. Curve hysteretic on Press reinforcement on right side column

Strand SG on left and right side columns

\section{Test result of lateral cyclic loads and drift ratio}

Lateral Cyclic loading results of a mock earthquake load (Pseudo-Dynamic) and magnitude of each load cycle can be read by the data logger, which can be seen from Thrust (press) and Pull force. The results of testing at each stage of deformation to inelastic stage at Story Drift $5.0 \%$ are arranged in a table as follows:

Table-2. Lateral Load V Data and Deflection at peak Column

\begin{tabular}{|c|c|c|c|c|c|c|}
\hline \multirow[t]{2}{*}{ No. } & $\begin{array}{l}\text { Press } \\
\text { Load } \\
\text { V }\end{array}$ & $\begin{array}{c}\delta \\
\operatorname{Tr} 2\end{array}$ & \multirow{2}{*}{$\begin{array}{c}\text { Story } \\
\text { Drift } \\
(\%)\end{array}$} & \multirow[t]{2}{*}{ No. } & $\begin{array}{l}\text { Pull } \\
\text { Load } \\
\text { V }\end{array}$ & $\begin{array}{c}\delta \\
\operatorname{Tr} 2\end{array}$ \\
\hline & $(\mathrm{kN})$ & $(\mathrm{mm})$ & & & $(\mathrm{kN})$ & $(\mathrm{mm})$ \\
\hline 0 & 0 & 0 & 0.000 & 0 & 0 & 0 \\
\hline 64 & 38.00 & 4.78 & 0.200 & 77 & -33.10 & -4.84 \\
\hline 90 & 36.40 & 4.80 & 0.200 & 103 & -32.40 & -4.86 \\
\hline 116 & 36.40 & 4.78 & 0.200 & 129 & -32.10 & -4.80 \\
\hline 155 & 47.60 & 6.04 & 0.250 & 170 & -38.30 & -5.94 \\
\hline 185 & 44.60 & 6.00 & 0.250 & 200 & -40.30 & -6.12 \\
\hline 215 & 44.00 & 5.92 & 0.250 & 230 & -40.00 & -6.02 \\
\hline 256 & 61.80 & 8.32 & 0.350 & 270 & -58.20 & -8.42 \\
\hline 284 & 59.20 & 8.36 & 0.350 & 298 & -55.90 & -8.28 \\
\hline 312 & 58.50 & 8.40 & 0.350 & 326 & -55.60 & -8.38 \\
\hline 351 & 77.70 & 11.96 & 0.500 & 366 & -75.40 & -11.92 \\
\hline 380 & 75.70 & 12.06 & 0.500 & 394 & -72.80 & -11.90 \\
\hline 408 & 70.50 & 12.00 & 0.500 & 422 & -70.50 & -12.08 \\
\hline 448 & 95.60 & 17.84 & 0.750 & 462 & -94.60 & -18.20 \\
\hline 476 & 93.30 & 17.90 & 0.750 & 490 & -92.00 & -17.86 \\
\hline 504 & 90.30 & 17.86 & 0.750 & 518 & -90.60 & -17.88 \\
\hline 544 & 108.50 & 23.86 & 1.000 & 558 & -106.20 & -23.80 \\
\hline 572 & 105.90 & 23.90 & 1.000 & 586 & -103.20 & -23.86 \\
\hline 600 & 103.90 & 23.90 & 1.000 & 614 & -101.90 & -23.84 \\
\hline 641 & 121.10 & 33.58 & 1.400 & 657 & -118.10 & -33.54 \\
\hline 673 & 114.50 & 33.42 & 1.400 & 689 & -115.50 & -33.58 \\
\hline 705 & 112.50 & 33.44 & 1.400 & 721 & -113.50 & -33.48 \\
\hline 749 & 125.40 & 42.76 & 1.750 & 765 & -124.70 & -41.94 \\
\hline 781 & 122.10 & 41.70 & 1.750 & 797 & -121.80 & -41.78 \\
\hline 813 & 120.40 & 41.66 & 1.750 & 829 & -120.40 & -42.80 \\
\hline 857 & 131.40 & 52.66 & 2.200 & 873 & -130.00 & -52.50 \\
\hline 889 & 128.70 & 52.54 & 2.200 & 905 & -127.10 & -52.28 \\
\hline 921 & 125.70 & 52.42 & 2.200 & 937 & -125.40 & -52.42 \\
\hline 966 & 138.00 & 65.60 & 2.750 & 984 & -133.70 & -65.56 \\
\hline 1002 & 134.00 & 65.50 & 2.750 & 1020 & -131.70 & -65.72 \\
\hline 1038 & 130.70 & 65.54 & 2.750 & 1056 & -130.40 & -65.56 \\
\hline 1086 & 138.30 & 82.78 & 3.500 & 1104 & -137.60 & -83.39 \\
\hline 1122 & 133.70 & 83.29 & 3.500 & 1140 & -134.30 & -83.39 \\
\hline 1158 & 130.70 & 83.29 & 3.500 & 1176 & -131.00 & -83.39 \\
\hline 1201 & 142.30 & 119.28 & 5.000 & 1218 & -135.70 & -128.78 \\
\hline 1217 & 131.40 & 119.78 & 5.000 & 1244 & -129.40 & -120.28 \\
\hline 1233 & 114.80 & 119.48 & 5.000 & 1270 & -99.30 & -120.18 \\
\hline $\begin{array}{l}\text { Load } \\
\text { max. }\end{array}$ & 142.30 & 119.28 & Bebal & aks: & -137.60 & -83.39 \\
\hline
\end{tabular}




\section{Momen capacity of Strand Tendon}

The following is an overview of Contributions Moment of Strand Tendons in accordance with ACI-3182008 part 21.5.2.5(c). Force and moment of the strand tendons: Beam using two Strand Tendons, strain gauge attached life is SG-31 (see figure 16).

From the reading of this strain gauge:

Pull load $=119.1 \mathrm{kN}$; Press load $=126.7 \mathrm{kN}$.

Calculation of Moment Capacity Strand Tendons:

$M n^{+}=\left(d p^{+}-\frac{a^{+}}{2}\right)$

After the calculation: $\mathrm{Mn}^{+}=28.68 \mathrm{kNm}$

For 2 strand $=2(28.68)=57.36 \mathrm{kNm}$

$\mathrm{Mn}^{-}=\mathrm{T}^{-}\left(\mathrm{dp}^{-}-\frac{\mathrm{a}^{-}}{2}\right)$

$\mathrm{a}^{-}=\frac{\mathrm{T}^{-}}{0,85 \mathrm{fc}^{\prime} \cdot \mathrm{b}}=\frac{126,7 \cdot 10^{3}}{0,85 \cdot 40 \cdot 250}=14,90 \mathrm{~mm}$

After the calculation: $\mathrm{Mn}^{-}=9.57 \mathrm{kNm}$

For 2 Strand $=2(9.57)=19.14 \mathrm{kNm}$

Force and moment of reinforcement:

At pull reinforcement:

On left side column: Strain gauge SG-6, 7 and 8 (see figure 12) the result read is: Pull load $119.1 \mathrm{kN}, 117.5 \mathrm{kN}$, 119.1kN. Read result Press load: 139.3 kN, 137 kN, 133.7 $\mathrm{kN}$. By taking the average of the three SGs:

$\mathrm{T}^{+}=1 / 3(119.1+117.5+119.1)=118.57 \mathrm{kN}$

$\mathrm{T}^{-}=1 / 3(139.3+137+133.7)=136.67 \mathrm{kN}$.

There are 5 Pull reinforcements:

Total $\mathrm{T}^{+}=5(118.57)=592.85 \mathrm{kN}$

Total $\mathrm{T}^{-}=5(136.67)=683.35 \mathrm{kN}$

On right side column: Strain gauge SG-19, 20 and 21 (see figure 13) the result read is: Pull load $118.8 \mathrm{kN}, 117.5 \mathrm{kN}$, and $116.1 \mathrm{kN}$. The result read at Press load is: $134 \mathrm{kN}$, $137 \mathrm{kN}$, and $139.3 \mathrm{kN}$. By taking the average of the three SGs:

$\mathrm{T}^{+}=1 / 3(118.8+117.5+116.1)=117.47 \mathrm{kN}$

$\mathrm{T}^{-}=1 / 3(134+137+139.3)=136.77 \mathrm{kN}$.

There are 5 Pull reinforcements:

Total $\mathrm{T}^{+}=5(117.47)=587.35 \mathrm{kN}$

Total $\mathrm{T}^{-}=5(136.77)=683.85 \mathrm{kN}$

Calculation of Moment Capacity Pull Reinforcing:

$\mathrm{Mn}^{+}=\mathrm{T}^{+}\left(\mathrm{d}^{+}-\frac{\mathrm{a}^{+}}{2}\right)$

On left side column:

$\mathrm{a}^{+}=\frac{\mathrm{T}^{*}}{0,85 \mathrm{fc}^{\prime} \cdot \mathrm{b}}=\frac{592,85 \cdot 10^{3}}{0,85 \cdot 40 \cdot 250}=69,74 \mathrm{~mm}$

After the calculation: $\mathrm{Mn}^{+}=187.12 \mathrm{kNm}$.

$\mathrm{Mn}^{-}=\mathrm{T}^{-}\left(\mathrm{d}^{-}-\frac{\mathrm{a}^{-}}{2}\right)$

$\mathrm{d}^{-}=\mathrm{d}^{+}=350,5 \mathrm{~mm} ; \mathrm{a}^{-}=80.40 \mathrm{~mm} ; \mathrm{Mn}^{-}=212.04 \mathrm{kNm}$.

On right side column:

$\mathrm{Mn}^{+}=\mathrm{T}^{+}\left(\mathrm{d}^{+}-\frac{\mathrm{a}^{+}}{2}\right)$

$\mathrm{a}^{+}=69.10 \mathrm{~mm} ; \mathrm{Mn}^{+}=185.57 \mathrm{kNm}$.

$\mathrm{Mn}^{-}=\mathrm{T}^{-}\left(\mathrm{d}^{-}-\frac{\mathrm{a}^{-}}{2}\right)$

$\mathrm{d}^{-}=\mathrm{d}^{+}=350,5 \mathrm{~mm} ; \mathrm{a}^{-}=80.45 \mathrm{~mm} ; \mathrm{Mn}^{-}=212.18 \mathrm{kNm}$.

At press renforcement:

On left side column: Strain gauge SG-11 and 12 (see figure 14), the result read is: Pull load $119.1 \mathrm{kN}, 111.2 \mathrm{kN}$, Press load: $134.3 \mathrm{kN}$ and $123.1 \mathrm{kN}$

The average of the two SGs are:
$\mathrm{T}^{+}=1 / 2(119.1+111.2)=115.15 \mathrm{kN}$

$\mathrm{T}^{-}=1 / 2(134.3+123.1)=128.7 \mathrm{kN}$

There are 3Pull reinforcements:

Total $\mathrm{T}^{+}=3(115.15)=345.45 \mathrm{kN}$

Total $\mathrm{T}^{-}=3(128.7)=386.1 \mathrm{kN}$

On right side column: Starin gauge SG-25 (see figure 15), the result is: Pull load $=116.5 \mathrm{kN}$, Press load $=122.4 \mathrm{kN}$

There are 3 Press reinforcements:

Total $\mathrm{T}^{+}=3(116,5)=349,5 \mathrm{kN}$

Total $\mathrm{T}^{-}=3(122,4)=367,2 \mathrm{kN}$

The calculation Capacity of Moment Reinforcement Press:

$\mathrm{Mn}^{+}=\mathrm{T}^{+}\left(\mathrm{d}^{+}-\frac{\mathrm{a}^{+}}{2}\right)$

On left side column:

After the calculation: $\mathrm{a}^{+}=40.64 \mathrm{~mm} ; \mathrm{Mn}^{+}=114.06 \mathrm{kNm}$.

$\mathrm{Mn}^{-}=\mathrm{T}^{-}\left(\mathrm{d}^{-}-\frac{\mathrm{a}^{-}}{2}\right)$

$\mathrm{d}^{-}=\mathrm{d}^{+}=350,5 \mathrm{~mm} ; \mathrm{a}^{-}=45.42 \mathrm{~mm} ; \mathrm{Mn}^{-}=125.56 \mathrm{kNm}$.

On right side column:

$\mathrm{Mn}^{+}=\mathrm{T}^{+}\left(\mathrm{d}^{+}-\frac{\mathrm{a}^{+}}{2}\right)$

$\mathrm{a}^{+}=41.12 \mathrm{~mm} ; \mathrm{Mn}^{+}=115.31 \mathrm{kNm}$.

$\mathrm{Mn}^{-}=\mathrm{T}^{-}\left(\mathrm{d}^{-}-\frac{\mathrm{a}^{-}}{2}\right)$

$\mathrm{d}^{-}=\mathrm{d}^{+}=350,5 \mathrm{~mm} ; \mathrm{a}^{-}=43.20 \mathrm{~mm} ; \mathrm{Mn}^{-}=120.77 \mathrm{kNm}$

The moment capacity of Structure:

Moment Capacity is a combination of Moment Capacity

Strand Tendons with Reinforcement Moment, either a positive or negative Moment.

The Compilation of Strand Tendons Moment with Pull Reinforcing Moment is:

a. On left side Column:

$\mathrm{Mn}^{+}=57.36+187,12=244.48 \mathrm{kNm}$

$\mathrm{Mn}^{-}=19.14+212,04=231.18 \mathrm{kNm}$.

b. On right side column:

$\mathrm{Mn}^{+}=57.36+185.57=242.93 \mathrm{kNm}$

$\mathrm{Mn}^{-}=19.14+212,18=231.32 \mathrm{kNm}$.

The Compilation Strand Tendons Moment with Compression Reinforcing Moment is:

a. On left side column:

$\mathrm{Mn}^{+}=57.36+114.06=171.42 \mathrm{kNm}$

$\mathrm{Mn}^{-}=19.14+126.56=245.70 \mathrm{kNm}$

b. On right side column:

$\mathrm{Mn}^{+}=57.36+115.31=172.67 \mathrm{kNm}$

$\mathrm{Mn}^{-}=19.14+120.77=139.91 \mathrm{kNm}$

Contributions Moment Capacity Strand Tendons to

Moment capacity Structure

In the pull reinforcement beam

On left side column:

Positive Moment:

$\mathrm{Mn}^{+}$Strand Tendon $=57.36 \mathrm{kNm}$, with total Capacity $\mathrm{Mn}^{+}$ $=244.48 \mathrm{kNm}$

The Percentage of Strand Tendon contribution:

$\mathrm{Mn}^{+}=\frac{57,36}{244,48} \times 100 \%=23.46 \%<25 \%(\mathrm{OK})$

Negative Moment:

$\mathrm{Mn}^{-}$Strand Tendon $=19.14 \mathrm{kNm}$, with total Capacity $\mathrm{Mn}^{-}$ $=231,18 \mathrm{kNm}$.

The Percentage of Strand Tendon contribution:

$=\frac{19,14}{231,32} \times 100 \%=8,27 \%<25 \%(\mathrm{OK})$ 
On right side column:

Positive Moment:

$\mathrm{Mn}^{+}$Strand Tendon $=57.36 \mathrm{kNm}$, total Capacity $\mathrm{Mn}^{+}=$ $242.93 \mathrm{kNm}$

The percentage of Strand Tendon contribution:

$$
\begin{aligned}
\mathrm{Mn}^{+}= & \frac{57,36}{242,93} \times 100 \%=23.61 \%<25 \%(\mathrm{OK}) \\
& \text { Negative Moment: }
\end{aligned}
$$

$\mathrm{Mn}^{-}$Strand Tendon $=19.14 \mathrm{kNm}$, with total Capacity $\mathrm{Mn}^{-}$ $=231.32 \mathrm{kNm}$.

The Percentage of Strand Tendon contribution:

$$
=\frac{19,14}{231,32} \times 100 \%=8,27 \%<25 \%(\mathrm{OK})
$$

In Compression Reinforcement beam:

On left side column:

Positive Momen:

$\mathrm{Mn}^{+}$Strand Tendon $=57.36 \mathrm{Nm}$, with total Capacity $\mathrm{Mn}^{+}$ $=171.42 \mathrm{kNm}$

The Percentage of Strand Tendon contribution:

$$
=\frac{57,36}{171,42} \times 100 \%=33,46 \%>25 \%(\text { Not OK) }
$$

Negative Moment:

$\mathrm{Mn}^{-}$Strand Tendon $=19.14 \mathrm{kNm}$, with total Capacity $\mathrm{Mn}^{-}$ $=231.32 \mathrm{kNm}$.

The Percentage of Strand Tendon contribution:

On right side column:

$=\frac{19,14}{231,32} \times 100 \%=8,27 \%<25 \%(\mathrm{OK})$

On right side column:

Positive Moment:

$\mathrm{Mn}^{+}$Strand Tendon $=57.36 \mathrm{Nm}$, with total Capacity $\mathrm{Mn}^{+}$ $=172.67 \mathrm{kNm}$

The Percentage of Strand Tendon contribution:

$=\frac{57,36}{171,42} \times 100 \%=33,46 \%>25 \%$ (Not OK)

Negative Moment:

$\mathrm{Mn}^{-}$Strand Tendon $=19.14 \mathrm{kNm}$, with total Capacity $\mathrm{Mn}^{-}$ $=139.91 \mathrm{kNm}$.

The Percentage of Strand Tendon contribution:

$\mathrm{Mn}^{+}=\frac{19,14}{139,91} \mathrm{X} 100 \%=13,68 \%<25 \% \ldots(\mathrm{OK})$

\section{Structure Ductility:}

In Story Drift $3.50 \%$ of the first cycle, it yielded boundary condition, while working press force cyclic: $\delta y=82.78 \mathrm{~mm}$. The stable condition on Drift Ratio $0.75 \%$ in first cycle, $\delta \mathrm{i}=17.84 \mathrm{~mm}$.

Level of Ductility $\mu=\delta y / \delta i \geq 4.0$

$\mu=82.78 / 17.84=4.64>4.0 \ldots \ldots \ldots .(\mathrm{OK})$

While working pull force cyclic: $\delta y=83.39 \mathrm{~mm}$

The stable condition on Drift Ratio $0.75 \%$ in first cycle, $\delta \mathrm{i}$ $=18.20 \mathrm{~mm}$.

Level of Ductility $\mu=\delta y / \delta \mathrm{i} \geq 4.0$

$\mu=83.39 / 18.20=4.58>4.0$

\section{DISCUSSIONS}

Maximum compressive lateral cyclic loading occurs at Drift Ratio of $5.0 \%$ in cycle $1=142.30 \mathrm{kN}, \delta_{\max }$ $=119.28 \mathrm{~mm}$, while the stable condition at Drift Ratio $0.75 \%$ in the first Cycle, $\delta \mathrm{i}=17.84 \mathrm{~mm}$. The maximum tensile force was happened on Drift Ratio $3.50 \%$ cycle- $1=$ $137.60 \mathrm{kN}$ with $\delta_{\max }=83.39 \mathrm{~mm}$, while the strain in stable condition at the drift ratio $0.75 \%$ in first Cycle, $\delta \mathrm{i}=18.20$ $\mathrm{mm}$. The compression maximum load on the drift ratio to $3.50 \%$ cycle-1 $=138.30 \mathrm{kN}$. The analysis will be performed on condition drift ratio of $3.50 \%$, because if the drift ratio is $3.50 \%$, the structural conditions are already qualified in accordance, therefore the frame structure of the building meets the structural reliability (NEHRP, 1997, ACI 318-2008, ACI 374.1- 05 and 374.2R-13).

From the analysis of the contribution of tendon moment capacity to the total capacity moment of beam, for area tensile, the positive moments in the left side column $=23.46 \%<25 \%(\mathrm{OK})$, the negative moments $=$ $8.28 \%<25 \%(\mathrm{OK})$, the positive moments on the right hand side column $=23.61 \%<25 \%(\mathrm{OK})$, and the negative moments $=8.27 \%<25 \%(\mathrm{OK})$. In the compression area, the positive moments in the left side column $=33.46 \%>$ $25 \%$ (not $\mathrm{OK}$ ), the negative moments $=8.27 \%<25 \%$ $(\mathrm{OK})$, while on the right hand side column, the positive moment $=33.22 \%>25 \%($ not $\mathrm{OK})$ and the negative moment $=13.68 \%<25 \%(\mathrm{OK})$.

The results of ductility analysis is that drift ratio is $3.50 \%$, compression ductility $\mu=4.64>4.0(\mathrm{OK})$, and tensile ductility $\mu=4.58>4.0(\mathrm{OK})$

The case of cracks on the column was only hairline cracks with two lines cross. Story Drift 5.0\% on the third cycle was inelastic conditions; reinforcing steel in the section beam of everything to break down. For Strand and reinforcing steel on top of the beam section through the drift ratio of $5.0 \%$, it had no break. Here is a figure of the pattern of cracks on the beams and columns:

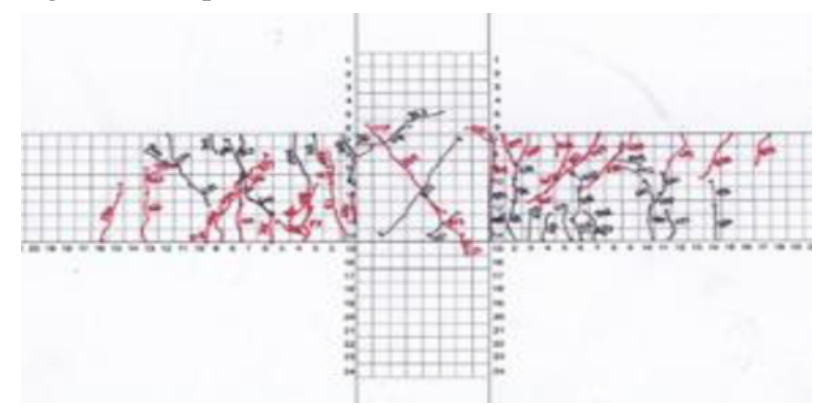

Figure-17. Fracture Pattern specimen

\section{CONCLUSIONS}

From the analysis test results of this model specimen, we can draw the following conclusions.

On the tensile region, the positive moment and negative moment both on the left side or the right side column are all qualified.

In the compression area, all positive moment on the left and right columns are not qualified, while, for the negative moment, the left or right-hand side column are all qualified.

Compression and tensile ductility on drift ratio of $3.50 \%$ is all qualified.

Although the contribution of positive moment capacity tendon in compression areas does not qualify, in overall, the reliability and ductility of the structure qualify.

\section{ACKNOWLEDGEMENTS}

In the writing and design of this research, we got a lot of help from various parties, especially Promoter Prof. Dr. Ir. I.G.P. Raka, DEA \& Prof. Tavio, ST, MS, Ph.D., I would like to show my gratitude. Thank yous also go to LPPM-ITS for financial support through the 
decentralization Ditlitabmas Research Programme, Directorate General of Higher DP2M Kemdikbud, PT. Wijaya Karya Beton and PT. Freyssinet Indonesia, as well as to all those who have helped the success of this research.

\section{REFERENCES}

American Concrete Institut(ACI 318M-08),, 2008 Building Code Requirements for Structural Concrete and Commentary. First Printing June 2008, 335 pp

Blackeley Roger W. G, Park Robert,. 1971 Seismic Resistance of Prestressed Concrete Beam-Column Assemblies. ACI Journal. 217 pp

Barbara Chang, et al., 2014. Seismic Performance of Beam-Column Subassemblies with Hight Strength Steel Renforcement. ACI Struktural Journal, 1330-1332 pp.

Dharma Astawa Made., 2006. Concrete Structure I, Teaching Modules, Grant Competition $\mathrm{A}_{1}$, Civil Engineering Department UPN "Veteran" East Java, Surabaya, ISBN : 978-979-1005-21-0.

Dharma Astawa Made., 2007. Earthquake Engineering, Teaching Modules, Civil Engineering Departement UPN "Veteran" East Java, Surabaya, ISBN:98-979-1005-20-3.

El-Sheikh Magdy T, et al., 1999. Seismic Behavior and Design of Unbonded Post-Tensioned Precast Concrete Frame. PCI Journal 512 pp.

Hawkins Neil M \&Ghosh S. K ,, 2000. Proposed Revision to 1997 NEHRP Recommended Provisions for Seismic Regulations for Precast Concrete Structures Part 2 Seismic Force Resisting Systems. PCI Journal,35-42 pp.

I Gusti Putu Raka., Tavio., Made Dharma Astawa., 2014. State-of-the-Art Report on Partially-Prestressed Concrete Earthquake-Resistant Building Structures for Highly-Seismic Region. Elsevier Prosedia Engineering 00 (2014), 3-11 pp.

Liang., Parra., 2004. Seismic Behavior of Reinforced Concrete Column-Steel Beam Subassemblies and Frame Systems. Journal of Structural Engineering @ ASCE, February 2004, 311-314 pp.

Lin T. Y, Burns Ned. H, Indrawan Daniel, 1996 “Desain Struktur Beton Prategang Jilid 1”, Erlangga Jakarta.

Lin T. Y, Burn Ned. H, Mediana., 2000. Desain Struktur Beton Prategang Jilid 2. Erlangga Jakarta.

Made D Astawa., Tavio., I G P Raka., 2013. Ductile Structure Framework of Earthquake Resistant of Highrise Building on Exterior Beam-Column Joint with the Partial Prestressed Concrete Beam-Column Reinforced Concrete. Elsevier Prosedia Engineering 54 (2013), 419-427 pp.

Nakano K, Tanabe K, Machida S, \& wada S., 2001. Damage Controlled Seismic Design by PrecastPrestressed Concrete Structure with Mild-Press-Joint,
Part 1, Basic Consept of Design, AIJ Summeries of Technical Papers of Annual Meeting, Japan, 1-5 pp.

Naaman Antoine. E., 1982. Prestressed Concrete Analysis and Design. McGrow-Hill Book Company, New York, San Francisco,Auckland, Bogota, Hamburg, Johannesburg, London, Madrid, atc.

Naaman Antoine E, Siriaksorn A., 1978. Analysis and Design of Partially Prestressed to Statisfy Serviceability Criteria. A Study Report by a Research Fellowship Award from tht Prestressed Concrete Institute and by the University of Illionis, Chicago, 12-17 pp.

Naaman Antoine E., 1985. Partially Prestressed Concrete (Review and Recommendation). special report, PCI. Journal, 112-116 pp.

Neil M. Hawkins., 1978. State-of-the-Art Report on Seismic Resistance of Prestressed and Precast Concrete Structures. PCI Journal/January-February 1978, 42-53 pp.

Paulay T, Priestley M. J. N., 1992. Seismic Design of Reinforced Concrete and Masonry Buildings. John Wiley \& Sons, New York, Chichester, Brisbane, Toronto, Singapore.

Raka I Gusti Putu., 1987. Speech ITS Anniversary Scientific in order to XXVII. ITS, November 1987

Raka I Gusti Putu., 1993. Ductility Sectional Round Hollow Prestressed Piles Compaction Centrifugal results. Research Report, Civil Engineering Departement, ITS Surabaya., 3-8 pp

Salah Khalfallah., Dahbia Guerdouh., 2014. Tension stiffening approach in concrete of tensioned members. International Journal of Advanced Structural Engineering 2014, 6:2, 2-6 pp.

Said M. Allam et al., 2013. Evaluation of tension stiffening effect on the crack width calculation of flexural RC members. Alexandria EngineeringJournal, January 2013, 164-172 pp.

Sergio M. Alcocer et al., 2013. Guide for Testing Reinforced Concrete Structural Elements under Slowly Applied Simulated Seismic Loads. Reported by ACI Committee 374.2R-13, 8-14 pp.

Shiohara Hitoshi., 2012. Reinforced Concrete BeamColumn Joints : an Overlooked Failure Mechanism and its Influence on the Future Seismic Design. Symposium on Earthquake and Resistance Building in Jakarta on Earthquake, Jakarta 17 Desember 2012, 5-7 pp.

SNI 03-2847., 2013. Procedure for Calcula-tion of Concrete Structures for Buildings, Concrete Laboratory ITS Surabaya.

SNI 03-1726-2012, Structure Earthquake Resistant Buildings. Badan Standardisasi Nasional (BSN), Jakarta.

S.V.Chaudhari., K.A.Mukane., M.A.Chakrabarti., 2014. Comparative study on Exterior RCC Beam Column Joint Subjected to Monotonic Loading. International Journal of 
Computer Applications (0975 - 8887) Volume 102- No.3, September 2014, 35-48 pp.

Tavio., Benny Kusuma., Prio Suprobo., 2012. Experimental Behavior of Concrete Columns Confined by Welded Wire Fabric as Transverse Reinforcement under Axial Compression. ACI Structural Journal, MayJune 2012, 2-4 pp

Thompson Kevin J., Park Robert., 1980. Ductility of Prestressed and Partially Prestressed Concrete Beam Section. PCI Journal, March-April 1980, 219-223 pp.

UBC., 1997. Uniform Building Code. Chapter 16, DIV. IV-1997. 